\section{Islet-cell Tumour Causing Hypoglycaemia in a Newborn Infant}

Hypoglycaemia due to islet-cell tumour is rare in children, and there have been few reports of its occurrence in newborn infants. Cases in which tumours were found post mortem have been described by Scholten and Van der Vegt (1960), Bernheim et al. (1961), and François et al. (1962). More recently, Salinas et al. (1968) and Garces, Drash, and Kenny (1968) described 2 infants with persistent hypoglycaemia which was relieved by resection of islet-cell tumours several weeks after delivery. 2 further infants with congenital isletcell tumours have been briefly reported by Drash et al. (1968) and Mann, Rayner, and Gourevitch (1969).

We wish to describe a further infant with an islet-cell tumour which caused severe hypoglycaemia soon after birth.

\section{Case Report}

The patient was a girl born at term weighing $4 \cdot 1 \mathrm{~kg}$. 2 hours after delivery she had a cyanotic attack, and her blood sugar was subsequently found to be less than $10 \mathrm{mg}$. $100 \mathrm{ml}$. 2-hourly feeds with added carbohydrate were given, together with intravenous infusions of glucose and fructose, but her hypoglycaemia persisted and she was transferred to this hospital at the age of 5 weeks. On admission she was an obese, unresponsive infant. Her weight was $4.8 \mathrm{~kg}$., her length $53 \mathrm{~cm}$., and her head circumference $38.5 \mathrm{~cm}$. No focal neurological signs were found, but occasional myoclonic jerks were seen.

Her treatment after admission is shown in the Fig. Attempts to control her hypoglycaemia by means of frequent feeding $(8 \mathrm{~g}$. SMA, Wyeth, and $4 \mathrm{~g}$. carbohydrate, 2-hourly) were unsuccessful, and treatment with increasing doses of diazoxide (up to $20 \mathrm{mg}$. $/ \mathrm{kg}$. per day) and chlorothiazide (15 mg./kg. per day) was given. As her hypoglycaemia persisted, and as she was sensitive to l-leucine (see below), her dietary leucine was restricted to $100 \mathrm{mg} . / \mathrm{kg}$. per day. This measure was also ineffective and she continued to have brief convulsions which could be rapidly controlled by giving glucose through a naso-gastric tube. Though she gained $2 \mathrm{~kg}$. in 9 weeks, there was no change in her head circumference and she showed little evidence of mental development.
When she was 14 weeks old, laparotomy was carried out by Mr. H. H. Nixon. As the pancreas appeared क and felt normal, partial pancreatectomy was performed. $\vec{\circ}$ An islet-cell tumour was subsequently found in the resected tissue (see below). On the day after operation $\vec{\omega}$ she appeared more alert and her convulsions stopped. On the 7 th post-operative day her wound required $\%$ re-suture, and healing was subsequently delayed by $?$ infection. However, her general condition continued or to improve, and 6 weeks after operation her motor and social behaviour were appropriate for her age. At the $\overrightarrow{.}$ age of 32 weeks her mental development was normal, $\vec{\omega}$ her head circumference had increased to $44 \mathrm{~cm}$., and $\neq$ her electroencephalogram (Dr. G. Pampiglione) showed 오 a minimal excess of slow activity but no focal or paroxysmal features. One brief convulsion occurred 13 days $\subset$ after operation but she has had no further fits.

Blood sugar and serum insulin. Serial blood $\vec{\varphi}$ sugar (glucose-oxidase method) and serum insulin (Grant, 1968) estimations were made before and after operation. Blood sugar and serum insulin were also estimated after giving 1-leucine (150 mg./kg.) by nasogastric tube or glucagon $(20 \mu \mathrm{g} / \mathrm{kg}$.) by intramuscular injection.

The serial blood sugar results before and immediately $\mathbb{D}$ after operation are shown in the Fig. Many values

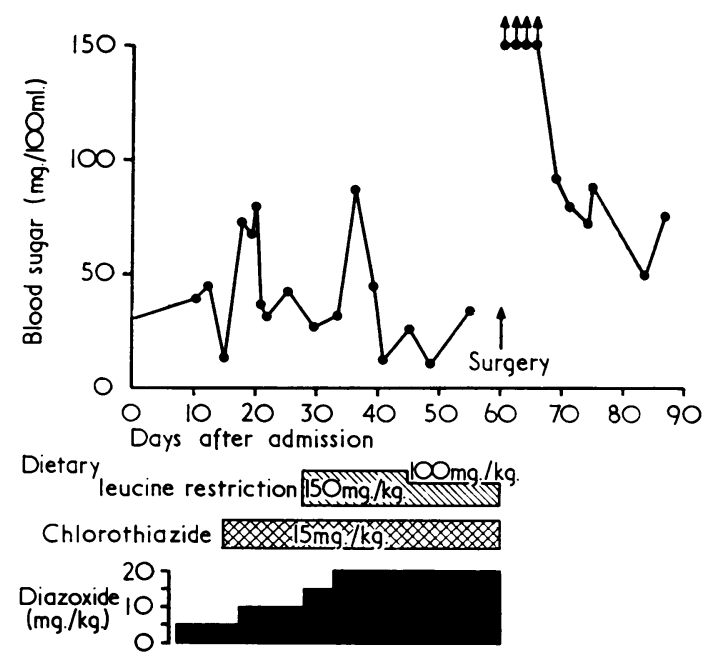

FIG.-Serial blood sugar values before operation (90-120 minutes after a feed) and during the early post-operative period (4 hours after a feed). The periods of treatment with diazoxide, chlorothiazide, and a restricted leucine diet are also shown. 
below $50 \mathrm{mg} . / 100 \mathrm{ml}$. were obtained 90-120 minutes after a morning feed during the period of treatment with diazoxide, chlorothiazide and a low leucine diet. During the first 3 days after operation the values ranged from $228 \mathrm{mg} . / 100 \mathrm{ml}$. to $395 \mathrm{mg} . / 100 \mathrm{ml}$. Subsequent blood sugar values 4-8 hours after a feed ranged from $47 \mathrm{mg}$. $/ 100 \mathrm{ml}$. to $87 \mathrm{mg} . / 100 \mathrm{ml}$.

Before operation, serum insulin levels between $25 \mu \mathrm{U} / \mathrm{ml}$. and $37 \mu \mathrm{U} / \mathrm{ml}$. were obtained at times when the blood sugar was less than $50 \mathrm{mg} . / 100 \mathrm{ml}$. After operation, insulin values between $2 \mu \mathrm{U} / \mathrm{ml}$. and 10 $\mu \mathrm{U} / \mathrm{ml}$. were obtained 8 hours after a feed.

The results of the leucine and glucagon tests are given in the Table. Before operation, leucine provoked a

TABLE

Serum Insulin and Blood Sugar Levels during Leucine and Glucagon Tests Performed a Week after Admission and 6 Weeks after Operation; Pre-operative Tests Begun 90 minutes after Feed and Post-operative Tests $4 \frac{1}{2}$ hours after Feed

\begin{tabular}{|c|c|c|c|c|}
\hline \multirow{2}{*}{$\begin{array}{l}\text { Time } \\
\text { From } \\
\text { Leucine or } \\
\text { Glucagon } \\
\text { (min.) }\end{array}$} & \multicolumn{2}{|c|}{ Before Operation } & \multicolumn{2}{|c|}{ After Operation } \\
\hline & $\begin{array}{c}\text { Serum } \\
\text { Insulin } \\
(\mu U / \mathrm{ml} .)\end{array}$ & $\begin{array}{c}\text { Blood } \\
\text { Sugar (mg./ } \\
100 \mathrm{ml} .)\end{array}$ & $\begin{array}{c}\text { Serum } \\
\text { Insulin } \\
(\mu \mathrm{U} / \mathrm{ml} .)\end{array}$ & $\begin{array}{c}\text { Blood } \\
\text { Sugar (mg./ } \\
100 \mathrm{ml} .)\end{array}$ \\
\hline $\begin{array}{c}\text { (a) Leucine } \\
-30 \\
-5 \\
+15 \\
+30 \\
+45 \\
+60 \\
\text { (b) Glucagon } \\
-30 \\
-5 \\
+15 \\
+30 \\
+45 \\
+60\end{array}$ & $\begin{array}{r}45 \\
24 \\
98 \\
128 \\
- \\
- \\
18 \\
\overline{160}+ \\
\overline{29} \\
25\end{array}$ & $\begin{array}{r}17 \\
12 \\
3 \\
2 \\
- \\
- \\
35 \\
13 \\
45 \\
64 \\
24 \\
14\end{array}$ & $\begin{array}{r}7 \\
8 \\
11 \\
12 \\
9 \\
7 \\
\\
\\
13 \\
9 \\
17 \\
18 \\
20 \\
15\end{array}$ & $\begin{array}{r}51 \\
56 \\
47 \\
35 \\
26 \\
34 \\
\\
59 \\
57 \\
107 \\
138 \\
136 \\
109\end{array}$ \\
\hline
\end{tabular}

profound fall in blood sugar and an excessive rise in serum insulin (Grant, 1968). Injection of glucagon was followed by a very high serum insulin value.

Pathological findings. The specimen of resected pancreas appeared normal but when sectioned after fixation, an ovoid, sharply circumscribed tumour $(0.5 \mathrm{~cm} . \times 0.5 \mathrm{~cm} . \times 1.0 \mathrm{~cm}$. $)$ was found in the tail. This tumour was composed of cords and nests of cells which contained $\beta$ granules (aldehyde-fuchsin stain) and which resembled normal islet-cells (Dr. P. Symchych).

\section{Discussion}

Though neonatal hypoglycaemia is usually transient, cases have been described in which severe hypoglycaemia persisted for weeks or months. In some of these the pancreatic islets appeared normal (Schwartz et al., 1955) or showed only minor histological changes (Crigler, 1962). In others, islet-cell tumours or generalized islet-cell hyperplasia (Haddad et al., 1962) were found.

Differentiation between insulinoma and a generalized $\beta$ cell abnormality may be difficult as leucine sensitivity may be present in either condition (Haddad et al., 1962; Garces et al., 1968). The clinical features of the present case suggested that hypoglycaemia was due to excessive insulin secretion. Though the laboratory findings confirmed this impression, they were not considered diagnostic of insulinoma, and uncertainty as to the cause of hyperinsulinism led us to start treatment with diazoxide. This drug has been used in the management of a number of children with hypoglycaemia, either alone or in combination with a thiazide, and has been found to inhibit leucineinduced insulin secretion in children with leucinesensitive hypoglycaemia (Baker et al., 1967). However, treatment with diazoxide was unsuccessful in 3 infants with congenital islet-cell tumours (Salinas et al., 1968; Garces et al., 1968; Drash et al., 1968). It was also ineffective in the present case, and it appears that failure to respond to diazoxide may be almost a diagnostic feature in infants with islet-cell tumours.

Failure of diazoxide therapy in our patient, together with clear evidence of hyperinsulinism, left little choice other than surgical treatment. After removal of her tumour she showed a remarkable improvement. Though it is still too early to assess whether she has completely escaped the neurological sequelae of severe hypoglycaemia, she showed rapid developmental 'catch up' after operation and her head began to grow. Similar improvement was noted in the cases described by Salinas et al. (1968) and Garces et al. (1968), and it has been suggested that the late prognosis after removal of an insulinoma is better than that in other forms of infantile hypoglycaemia (Crigler, 1962).

\section{Summary}

The clinical features of an infant with an islet-cell tumour are described. Hypoglycaemia, which began 2 hours after delivery, failed to respond to treatment with diazoxide, chlorothiazide, and a low leucine diet but was relieved by removal of the tumour at the age of 14 weeks. Rapid developmental 'catch up' occurred after the operation.

We wish to thank Dr. G. H. Newns for allowing us to publish this case report; Dr. A. G. Hesling for referring the patient; and Dr. Barbara Clayton and her staff for the blood sugar and serum insulin determinations. 


\section{REFERENCES}

Baker, L., Kaye, R., Root, A. W., and Prasad, A. L. N. (1967). Diazoxide treatment of idiopathic hypoglycemia of infancy. Fournal of Pediatrics, 71, 494.

Bernheim, M., Larbre, F., François, R., Gilly, R., and Pradon, M. (1961). Hypoglycémie mortelle par adenome des ilots de Langerhans du pancréas chez le nouveau-né. Pédiatrie, 16, 631.

Crigler, J. F., Jr. (1962). Idiopathic hypoglycemia: discussion of a case. New England fournal of Medicine, 266, 1270.

Drash, A., Kenny, F., Field, J., Blizzard, R., Langs, H., and Wolff, F. (1968). The therapeutic application of diazoxide in pediatric hypoglycemic states. Annals of the New York Academy of Sciences, 150, 337.

François, R., Pradon, M., Sherrer, M., and Ugliengo, A. R. (1962). Hypoglycemia due to pancreatic islet cell adenoma. Fournal of Pediatrics, 60, 721.

Garces, L. Y., Drash, A., and Kenny, F. M. (1968). Islet cell tumor in the neonate. Studies in carbohydrate metabolism and therapeutic response. Pediatrics, 41, 789.

Grant, D. B. (1968). Serum-insulin changes following administration of L-leucine to children. Archives of Disease in Childhood, $43,69$.

Haddad, H. M., Roberts, W. C., Pronove, P., and Barter, F. C. (1962). Leucine-induced hypoglycemia. New England fournal of Medicine, 267, 1057.

Mann, J. R., Rayner, P. H. W', and Gourevitch, A. (1969). Insulinoma in childhood. Archives of Disease in Childhood, 44, 435.

Salinas, E. D., Jr., Mangurten, H. H., Roberts, S. S., Simon, W. H., and Cornblath, M. (1968). Functioning islet cell adenoma in the newborn. Report of a case with failure of diazoxide. Pediatrics, 41, 646.

Scholten, H. G., and Van der Vegt, J. H. (1960). Functionerend eilandceladenoom van het pancreas bij een pasgeboren. Maandschrift voor Kindergeneeskunde, 28, 140.

Schwartz, O., Goldner, M. G., Rosenblum, J., and Avin, J. (1955). Neonatal hypoglycemia. Report of a case of unusual duration. Pediatrics, 16, 658.

D. B. GRANT and P. R. H. BARBoR*

The Hospital for Sick Children, Great Ormond Street, London W'C1

^Present address: Queen Elizabeth Hospital for Children, Hackney Road, London E2.

\section{Suspending Agents in Medicaments as Possible Sources of Galactose to Galactosaemic Child}

The need to exclude galactose from the diet of galactosaemic patients is well understood, and the difficulties of achieving this have been well documented. As little as $250 \mathrm{mg}$. lactose administered daily as a tablet excipient to a galactosaemic child has been reported sufficient to arrest weight gain (Bower and Smallpeice, 1955).

Tragacanth and acacia (gum arabic) are widely used as suspending agents in pharmaceutical liquid preparations; for example several of the BPC or
NF oral suspensions, and sulphadimidine paediatric mixture BNF. Both these gums, as well as carrageenan (Irish Moss) and agar, are used extensively in the food industry. All four are complex galactosides, and therefore potential sources of galactose. A galactosaemic child prescribed two suspensions concurrently for 6-hourly administration would receive $40 \mathrm{ml}$. of mixture equivalent to $500 \mathrm{mg}$. gum daily, in addition to intake from foods and confectionery products.

The purpose of our investigation was to find whether these compounds may be hydrolysed in vivo to free galactose.

\section{Experimental Work}

The concentrations of tragacanth, acacia, agar, and carrageenan used in the following experiments were those normally found in liquid pharmaceuticals and foods. In each experiment, products of hydrolysis were demonstrated by thin-layer chromatography.

(1) Each gum was heated with strong acid at $100{ }^{\circ} \mathrm{C}$ for 4 hours. Products of hydrolysis were demonstrated on Silica Gel G absorbent using chloroform/acetic acid/ water $(6 / 7 / 1)$ as solvent and $\alpha$-naphthol/sulphuric acid for visualization.

(2) Each material was incubated at $37^{\circ} \mathrm{C}$. with crude malt diastase ( $\alpha$ - and $\beta$-amylase) for 2 hours.

(3) A solution of each gum was incubated with human salivary amylase together with a jejunal biopsy specimen of proven normal lactase activity. Each solution was adjusted to $\mathrm{pH} 6.5$ in the presence of chloride ions $(0 \cdot 1 \%)$, and incubated at $37^{\circ} \mathrm{C}$. Controls of starch for $\alpha$-amylase activity, and lactose for lactase activity were incubated to confirm suitable conditions for enzymic digestion.

(4) Solutions, and controls as above, were incubated with hog pancreatic $\alpha$-amylase and human disaccharidase. Each tube was adjusted to $p \mathrm{H} 6 \cdot 5$, and incubated at $37^{\circ} \mathrm{C}$.

Several chromatographic systems were examined, and optimum separation was found with cellulose MN 300 as adsorbent $250 \mu$ thick, and ethyl acetate/pyridine/ water $(2 / 1 / 2)$ as solvent. Using aniline phthalate for visualization, $0.5 \mathrm{\mu g}$. galactose could be detected. This procedure was used in all experiments except (1).

\section{Results}

The results are shown in the Table.

It will be noted that free galactose was identified after stong acid treatment, and after digestion with $\beta$-amylase. This enzyme is not present in mammalian tissue but commonly occurs in plants and bacteria. Results from incubation with saliva and jejunal enzyme failed to demonstrate galactose after 24 hours, though both controls gave positive results when tested after 1 hour. Similarly, analysis of samples treated for 24 hours with 